\title{
Fiber Reinforced Concrete Segmental Tunnels in Seismic Regions
}

\author{
Mohammad Jamshidi Avanaki* \\ School of Civil Engineering, University of Tehran, Iran
}

Submission: September 12, 2019; Published: September 26, 2019

*Corresponding author: Mohammad Jamshidi Avanaki, School of Civil Engineering, College of Engineering, University of Tehran, 14155-6457 Tehran, Iran

\begin{abstract}
The usage of fibers in concrete segmental tunnels has led to considerable structural and durability improvements. In seismic regions, structures are designed to resist earthquake effects and maintain their functionality. Therefore, it is necessary to specifically study the structural behavior and response of Fiber Reinforced Concrete (FRC) segmental tunnels for their reliable implementation in seismically active zones. Recent research efforts in this regard show the favorable performance of FRC under earthquake loadings. Yet, further research is required to better understand the various aspects of FRC segmental tunnel performance under seismic loading and develop a seismic design framework.
\end{abstract}

Keywords: Fiber reinforced concrete; Segmental tunnel; Seismic performance

\section{Mini Review}

The ever-growing construction sector is considered as one of the main propellers of economy, especially in developing countries. Tunnels are one of the vastly developed infrastructures in which public and private sectors build and invest for various purposes, e.g. transport, water supply, and so on. In this regard, approaches to increase feasibility and performance of tunnels are developed to meet specific requirements. Introduction and usage of fibrous materials to strengthen mortar matrix, i.e. primarily decrease crack development and propagation, dates back to centuries ago [1]. In modern construction practice, fibers of different materials (steel, carbon, glass, polypropylene, ...) are used to increase the post-crack tensile strength and flexural properties of the concrete mortar [1-3], known as Fiber Reinforced Concrete (FRC). The design framework for fiber reinforced concrete structural elements are standardized and introduced in recent design codes and regulations [4-6].

The idea to use fibers as the main reinforcement mechanism in replacement of reinforcing bars in concrete segmental tunnels has been investigated in various research efforts [7-9] and practiced in numerous projects worldwide [9]. It has been shown that fibers improve both structural [10-12] and durability [13] of the segmental tunnel. Studies on the performance of FRC tunnels are mainly focused on loading conditions normally experienced from the tunnel assembly phase (e.g. TBM jack loads [14]) to the operational phase (e.g. symmetric ground pressures, static water pressures, so on). Yet, in seismic regions, all structures should be specifically designed to withstand the earthquake loading effects in a reliable and feasible manner.

Underground tunnels have historically shown better performance than above ground structures in a seismic event [15]. Despite this fact, slight to major damage scenarios has been reported in underground tunnels in the aftermath of an earthquake $[16,17]$. This issue emphasizes the need to specifically investigate the structural behavior and response of FRC segmental tunnels for their reliable implementation in seismically active zones. In this regard, research on the seismic performance of FRC segmental tunnels has recently gained interest and significance. Jamshidi Avanaki et al. [18] investigated the seismic vulnerability of Steel FRC (SFRC) segmental tunnels under earthquake loadings using a performance-based approach. They initially conducted an experimental program to characterize various SFRC composites and obtain their mechanical properties. A macro and micro steel fiber was used to produce both hybrid $[12,19,20]$ and non-hybrid SFRC mixes. The mechanical properties of the SFRC composites to develop a soil-tunnel finite element model. The soil-tunnel system was subjected to various earthquake loadings, i.e. different earthquake records and seismic intensities. After introducing a novel damage index for segmental tunnels, the seismic performance of the tunnel was studied using numerically developed fragility curves [21]. They concluded that steel fibers, especially micro size fibers and for higher states of damage, display better seismic performance over conventional steel rebar in segmental lined tunnels. For best 


\section{Civil Engineering Research Journal}

performance, a hybrid SFRC mix containing both micro and macro fibers, with a higher content of microfibers over macro ones, is a technically preferable option for the design of segmental lining tunnels in seismic zones.

In another study by Jamshidi Avanaki et al. [22], the performance of segmental joints, i.e. the joints connecting to adjacent segments in a ring, under seismic loads was studied. The results showed that the SFRC mixes enhance the seismic performance of the joint compared to plain concrete (no rebar) or traditionally reinforced (with rebar) concrete. Finally, equations were proposed to estimate the joint's moment demand/capacity ratio and rotational ductility for seismic design. In an experimental study by Xin et al. [23], a series of shaking table tests was conducted using scaled tunnel specimens with plain concrete, steel reinforced concrete and polypropylene FRC under increasing seismic intensities loadings. Their results displayed the advantageous behavior of the polypropylene fiber to change the brittle behavior of plain concrete, change the damage patterns of reinforced concrete with rebar, reduction in the number of initial micro cracks, postpone the appearance of new cracks, prevent the propagation of macro cracks and relieve the stress concentration at the ends of fibers. In an effort to facilitate the seismic design of SFRC segmental tunnels, Jamshidi Avanaki [24] investigated the seismic ductility properties of such tunnels and derived R-factors for their seismic design.

\section{Conclusion}

The advantageous aspects of incorporating fibers in full or partial replacement of conventional rebar has been proven in many previous research efforts. Research conducted so far is focused on normal loading scenarios experienced in the lifespan of a tunnel. Yet, tunnels located in seismically active regions should be capable to perform in a favorable manner under earthquake effects. The seismic performance of FRC tunnels is a subject which despite recent efforts, requires much further research and investigation to ensure a safe and feasible design.

\section{References}

1. Mobasher B (2011) Mechanics of fiber and textile reinforced cement composites. CRC Press.

2. Hannant DJ (1978) Fiber Cements and Fiber Concrete. John Wiley \& Sons, Chichester, UK.

3. Monfore G (1968) A review of fiber reinforcement of Portland cement paste, mortar and concrete. Journal Pca Res \& Dev Laboratories.

4. fédération internationale du béton (fib), Model Code 2010, in fib Bulletins, Lausanne (Switzerland). PP. 65-66

5. (2003) RILEM TC 162-TDF $\sigma-\varepsilon$ design method-final recommendation. Materials and structures 36: 560-570.

6. (1988) American Concrete Institute (ACI) 544 committee report on Fiber Reinforced Concrete.

7. Kasper T, Edvardsen C, Wittneben G, Neumann D (2008) Lining design for the district heating tunnel in Copenhagen with steel fibre reinforced concrete segments. Tunnelling and Underground Space Technology 23(5): 574-587.

8. Caratelli A (2011) Structural behaviour of precast tunnel segments in fiber reinforced concrete. Tunnelling and Underground Space Technology 26(2): 284-291.

9. Albert De la Fuente A (2012) Experiences in Barcelona with the use of fibres in segmental linings. Tunnelling and Underground Space Technology 27(1): 60-71.

10. Buratti N, Ferracuti B, Savoia M (2013) Concrete crack reduction in tunnel linings by steel fibre-reinforced concretes. Construction and Building Materials 44(6): 249-259.

11. Chiaia B, Fantilli AP, Vallini P (2009) Combining fiber-reinforced concrete with traditional reinforcement in tunnel linings. Engineering Structures 31(7): 1600-1606.

12. Jamshidi Avanaki M, Abedi M, Hoseini A (2019) Experimental and numerical-based design of hybrid steel fibre-reinforced concrete tunnels. Magazine of Concrete Research.

13. Caggiano A (2017) On the mechanical response of Hybrid Fiber Reinforced Concrete with Recycled and Industrial Steel Fibers. Construction and Building Materials 147: 286-295.

14. Meda A, Rinaldi Z, Caratelli A, Cigniti F (2016) Experimental investigation of precast tunnel segments under TBM thrust action. Tunnelling and Underground Space Technology 119: 174-185.

15. Hashash YMA (2001) Seismic design and analysis of underground structures. Tunnelling and Underground Space Technology 16(4): 247-293.

16. Yashiro K, Kojima Y, Shimizu M (2007) Historical earthquake damage to tunnels in Japan and case studies of railway tunnels in the 2004 Niigataken-Chuetsu earthquake, in Quarterly Report of Railway Technical Research Institute. Pp.136-141.

17. Power M, Rosidi D, Kaneshiro J (1998) Seismic vulnerability of tunnelsrevisited. in North American Tunneling Conference, Long Beach, CA, USA.

18. Jamshidi Avanaki M (2018) Seismic fragility curves for vulnerability assessment of steel fiber reinforced concrete segmental tunnel linings. Tunnelling and Underground Space Technology 78: 259-274.

19. Banthia N, Soleimani SM (2005) Flexural response of hybrid fiberreinforced cementitious composites. ACI Materials Journal 102(6): 18-25.

20. Banthia N, Yan C, Bindiganavile V (2000) Development and application of high performance hybrid fiber reinforced concrete. in the fifth international RILEM symposium on fibre-reinforced concrete, Lyon, France.

21. (2004) FEMA and National Institute of Building Science, HAZUS-MH: Technical Manuals. 2004: Washington, DC.

22. Jamshidi Avanaki M (2018) Numerical-aided design of fiber reinforced concrete tunnel segment joints subjected to seismic loads. Construction and Building Materials 170: 40-54.

23. Xin CL (2019) Shaking table tests on seismic behavior of polypropylene fiber reinforced concrete tunnel lining. Tunnelling and Underground Space Technology 88: 1-15.

24. Jamshidi Avanaki M (2019) Response modification factors for seismic design of steel Fiber Reinforced Concrete segmental tunnels. Construction and Building Materials 211: 1042-1049. 

(C) This work is licensed under Creative DOI: 10.19080/CERJ.2019.09.555756

\section{Your next submission with Juniper Publishers} will reach you the below assets

- Quality Editorial service

- Swift Peer Review

- Reprints availability

- E-prints Service

- Manuscript Podcast for convenient understanding

- Global attainment for your research

- Manuscript accessibility in different formats

( Pdf, E-pub, Full Text, Audio)

- Unceasing customer service

Track the below URL for one-step submission https://juniperpublishers.com/online-submission.php 